\title{
Integrasi Dinamis Pasar Modal Indonesia Dengan Pasar Modal In- ternational Pada Masa Pandemi Covid-19
}

\author{
Stefany Cindy Sugiyanto, dan Robiyanto \\ Departemen Manajemen Fakultas Ekonomika dan Bisnis Universitas Kriten Satya Wacana (UKSW) \\ Jl. Diponegoro No. 52-60, Salatiga 50711, Indonesia
}

\section{Info Artikel}

Keywords:

Covid-19; DCC-GARCH; Dynamic Integration; and Stock Market Integration.
Kata Kunci:

Covid-19; DCC-GARCH; Integrasi Dinamis; dan Integrasi Pasar Modal.

ISSN (print): 2598-7763 ISSN (online): 2598-7771

$\triangle$ Corresponding Author: Robiyanto Tel. /Fax. +62 818-646-633 E-mail: robiyanto@staff.uksw.edu

\begin{abstract}
Abtract
The Covid-19 pandemic has an impact on the world economy especially on the stock market, thus the aim of this study is to determine whether there is dynamic integration between the stock markets in Indonesia with the capital market in Asia and in the world during Covid-19 pandemic. This study uses return data from the closing price of 12 stock indices, namely ASX, DOWJONES, FTSE, HANGSENG, IHSG, KLSE, KOSPI, NIKKEI, PSEI, SET, STI, and TAIWAN from January to December 2020 that have been analyzed using DCC-GARCH. The results showed that the stock markets of both Indonesia, Asia and the world were dynamically integrated due to the global crisis of the Covid-19 pandemic. The results showed that there was a contagion effect on the stock market that occurred during the period when the Covid-19 pandemic crisis occurred. This research can be a reference for investors who want to invest in stocks in Indonesia during the Covid-19 pandemic
\end{abstract}

Citation: Sugiyanto, S.C dan Robiyanto. (2020). Integrasi Dinamis Pasar Modal Indonesia dengan Pasar Modal di Asia dan Pasar Modal di Dunia pada Masa Pandemi Covid-19. AFRE Accounting and Financial Review. 3(2): 142-150

\begin{abstract}
Abstraks sia selama masa pandemi Covid-19.

JEL Classification: G20, G21

DOI: https://doi.org/10.26905/afr.v3i2.551
\end{abstract}

Pandemi Covid-19 menyebabkan pengaruh terhadap perekonomian dunia terutama memberikan dampak terhadap pasar saham, oleh karena itu tujuan dari penelitian ini adalah untuk mengetahui apakah terjadi integrasi dinamis antara pasar saham yang berada di Indonesia dengan pasar modal yang berada di Asia dan pasar modal di dunia di masa pandemi Covid-19. Penelitian ini menggunakan data return harga penutupan dari 12 pasar modal yakni ASX, DOWJONES, FTSE, HANGSENG, IHSG, KLSE, KOSPI, NIKKEI, PSEI, SET, STI, dan TAIWAN pada periode Januari hingga Desember 2020 yang dianalisis menggunakan teknik DCC-GARCH. Hasil penelitian menunjukkan bahwa pasar saham baik Indonesia, Asia dan dunia terintegrasi secara dinamis akibat krisis global pandemi Covid-19. Hasil penelitian menunjukkan bahwa terdapat efek penularan di pasar saham yang terjadi pada periode saat terjadinya krisis pandemi Covid-19. Hasil penelitian ini dapat menjadi referensi bagi investor yang ingin melakukan investasi saham di Indone-

\section{PENDAHULUAN}

Pandemi global virus corona atau yang dikenal sebagai Covid-19 telah menjangkit seluruh dunia dan mengancam semua negara termasuk Indonesia. IMF dan Bank dunia memprediksi pandemi Covid-19 telah memicu resesi ekonomi global. Sejumlah kalangan pakar memperki-rakan dampaknya setara atau lebih buruk dari kondisi great depression pada periode 1920-1930 (WHO, 2020).

Kondisi ini membuat aktivitas ekonomi pun terdampak. Di Indonesia sendiri IHSG menduduki ranking ke-5 di kawasan ASEAN dengan penurunan sebesar $28,63 \%$ sejak awal tahun secara 
year to date (ytd) ke level 4.496 (Kontan, 2020). IHSG cenderung mengalami penurunan secara tajam di awal Januari 2020 hingga April 2020 (Dewi \& Masithoh, 2020) Di saat yang bersamaan berdasarkan data dari Investing.com, indeks DOWJONES juga mengalami penurunan drastis sebanyak 7,79\% di angka 23.851,02. Dari hal tersebut peneliti menduga bahwa terjadi korelasi antara krisis ekonomi secara global dengan indeks saham di dunia yang turut memengaruhi IHSG.

Tujuan penelitian ini difokuskan untuk mengkaji integrasi dinamis pasar saham Indonesia dengan pasar saham di Asia dan pasar saham di dunia pada masa pandemi Covid-19. Catherine \& Robiyanto (2020) dalam penelitiannya menemukan bahwa terdapat integrasi antara pasar modal di kawasan Asia dan AS pasca pelantikan Donald Trump. Penelitian lain yang dilakukan oleh Mohti et al., (2019) tentang integrasi pasar modal di Asia secara regional dan global ditemukan bahwa terdapat korelasi dalam jangka panjang antara pasar modal Indonesia, Korea, Filipina dan Thailand dengan Jepang sebagai tolok ukur regional, dan antara pasar modal di Korea, Taiwan, Malaysia, Indonesia, dan Thailand dengan AS sebagai tolok ukur pasar modal global.

Penelitian ini menggunakan landasan teori integrasi pasar modal dimana menurut Rasydin (2016) dalam penelitiannya menyebutkan bahwa terjadinya integrasi antar pasar saham disebabkan adanya kesamaan pasar dalam pola pendapatan, dan ini memberikan kontribusi positif terhadap makroekonomi dalam negeri, dapat memfasilitasi aliran modal daerah ke pasar multinasional, transformasi teknologi, deregulasi keuangan memungkinkan investor untuk memperluas portofolio mereka secara internasional, dan perdagangan internasional dan mendorong hubungan ekonomi yang lebih kuat.

Menurut Sakthivel et al., (2012), harga pasar saham dapat dipengaruhi oleh informasi fundamental ekonomi pasar saham suatu negara. Dengan demikian dibuktikan bahwa pasar modal Indonesia yang merupakan negara berkembang dipengaruhi oleh pasar modal negara yang maju (Utama \& Artini, 2013).

Selain itu, lawan dari pasar modal terintegrasi adalah pasar saham tersegmentasi, yang didefinisikan sebagai pasar yang membatasi pergerakan arus modal dengan bebas, dan return yang diharapkan dari aset yang sama di negara yang berbeda (Robiyanto, 2018). Darrat et al., (2000) dalam penelitiannya menemukan bahwa pasar MENA (Mesir, Maroko, dan Yordania) tersegmentasi secara global dan terintegrasi secara regional.

Belum banyak penelitian yang mengkaji bagaimana kondisi pasar modal baik Indonesia, Asia dan Dunia pada masa gejolak ekonomi akibat pandemi Covid-19. Sehingga penelitian ini diharapkan dapat memberikan gambaran mengenai kondisi pasar modal di situasi pandemi Covid-19 dan diharapkan bisa menjadi acuan dalam pengambilan keputusan bagi investor serta menjadi referensi literasi mengenai integrasi pasar modal dengan peristiwa pandemi Covid-19.

\section{PENGEMBANGAN HIPOTESIS}

Catherine \& Robiyanto (2020) menemukan bahwa terdapat integrasi antara pasar modal di kawasan Asia dan AS pasca pelantikan Donald Trump dengan hasil uji VAR (Analisis Vector Autoregressions) indeks DOWJONES berpengaruh signifikan terhadap seluruh indeks di Asia (STI, IHSG, KLSE, KOSPI, NIFTY, NIKKEI, PSEI, SETI, dan SSEC). Selain itu penelitian Robiyanto (2018) yang menggunakan DCC-GARCH (Dynamic Conditional Correlation-GARCH) juga menemukan bahwa hubungan dinamis antara pasar saham Indonesia dengan pasar saham di Asia dan dunia selalu berubah seiring waktu. Nilai DCC-GARCH antara IHSG dan indeks pasar saham yang diteliti kecuali pasar saham Australia, bursa efek Filipina, dan bursa Tokyo cenderung meningkat dari periode sebelum krisis, selama masa krisis dan masa pasca krisis. Penelitian lain yang dilakukan Nurazi et al., (2013) tentang kointegrasi pasar modal Indonesia dan Tiongkok menemukan bahwa terdapat ketergantungan yang tinggi antar pasar modal di kedua negara tersebut dan pasar modal Tiongkok lebih mendominasi pasar modal Indonesia, sehingga guncangan di pasar modal Tiongkok akan berdampak pada pasar modal Indonesia. Temuan penelitian lain yang dilakukan oleh Ersabathari \& Muharam (2017) menemukan jika pasar modal ASEAN 6 secara keseluruhan telah terintegrasi.

Munculnya wabah virus corona atau Covid-19 di Indonesia membuat pasar modal mengalami penurunan. Wabah virus corona atau Covid-19 telah berdampak negatif pada pasar saham dan pasar keuangan di dalam negeri, hingga mencetak rekor baru dan mengakibatkan Indeks Harga Saham Gabungan atau (IHSG ) anjlok dan terpukul ke level yang cukup rendah (Shiyammurti et al., 2020). Tandelilin (2010) menyatakan bahwa faktor-faktor makroekonomi se- 
cara empiris telah terbukti mempunyai pengaruh terhadap kondisi pasar modal di beberapa Negara. Oleh sebab itu, pergerakan Indeks Harga Saham Gabungan (IHSG) di BEI sangat dipengaruhi oleh beberapa faktor makroekonomi. Berdasarkan kajian-kajian terdahulu, maka hipotesis dalam penelitian ini adalah:

$\mathrm{H}_{1}$ : Terdapat integrasi pasar modal Indonesia dengan pasar modal di Asia dan pasar modal di dunia pada masa pandemi Covid-19.

\section{DATA DAN METODE}

Sumber data yang terdapat dalam penelitian ini menggunakan data sekunder dari harga penutupan harian masing-masing indeks saham di kawasan Asia dan dunia yang terdiri dari Indonesia (IHSG), Malaysia (KLSE), Singapura (STI), Thailand (SET), Philipina (PSEi), Korea (KOSPI), Hongkong (HSI), Jepang (Nikkei225), Taiwan (TaipeiWG), New York (DowJones), Inggris (FTSE), dan Australia (ASX). Data yang diambil antara periode 1 Januari hingga 31 Desember 2020, karena dalam jangka waktu tersebut mulai terjadi pandemi Covid-19. Data dari masingmasing indeks diperoleh dari www.investing.com.

Pada penelitian ini meneliti return pasar saham dengan menggunakan variabel dari 12 pasar saham di kawasan Asia dan dunia yang dihitung dari setiap data perharinya, dengan menggunakan rumus sebagai berikut:

$$
\text { Rmit }=\left[\frac{I_{i t}-I_{i t}-1}{I_{i t}-1}\right]
$$

Keterangan: $\mathrm{Rm}_{\mathrm{it}}=$ return pasar saham i pada periode $\mathrm{t}$; $\mathrm{I}_{\mathrm{it}}=$ Penutupan indeks harga saham i di bursa efek yang diteliti pada periode $\mathrm{t}$; $\mathrm{I}_{\mathrm{it}-1}=$ Penutupan indeks harga saham i di bursa efek yang diteliti pada periode $\mathrm{t}-1$

Dalam penelitian ini teknik analisis yang digunakan adalah Dynamic Conditional CorrelationGeneralized Autoregressive Conditional Heteroscedasticity (DCC-GARCH). Model yang digunakan untuk mengukur korelasi pasar saham ini diperkenalkan oleh Engle (2002). Model ini digunakan karena dapat mengetahui secara dinamis perilaku investor, dalam menanggapi berita dan inovasi. Selain itu, model ini sangat tepat untuk menguji efek penularan yang mungkin terjadi karena perilaku herding di pasar negara berkembang selama krisis keuangan (Hwang, 2012). Untuk mengukur korelasi antar pasar, terdapat dua langkah prosedur estimasi model DCC yaitu, univariate GARCH, dan langkah berikutnya adalah membuat estimasi DCC antar pasar keuangan.

Model DCC dapat dirumuskan dengan beri- kut ini:

$\mathrm{r}_{\mathrm{t}} \mid==_{\mathrm{t}-1} \sim \mathrm{N}\left(0, \mathrm{D}_{\mathrm{t}} \mathrm{R}_{\mathrm{t}} \mathrm{D}_{\mathrm{t}}\right)$

$\mathrm{D}^{2} \mathrm{t}=\operatorname{diag}\left\{\omega_{\mathrm{i}}\right\}+\operatorname{diag}\left\{\mathrm{K}_{\mathrm{i}}\right\}^{\circ} \mathrm{r}_{\mathrm{t}-1} \mathrm{r}_{\mathrm{t}-1}^{\prime}+\operatorname{diag}\left\{\lambda_{\mathrm{i}}\right\}^{\circ} \mathrm{D}^{2} \mathrm{t}-1$

$\varepsilon_{\mathrm{t}}=\mathrm{D}_{\mathrm{t}-1} \mathrm{r}_{\mathrm{t}}$

$\mathrm{Q}_{\mathrm{t}}=\mathrm{S}^{\circ}\left(\mathrm{t} \mathrm{t}^{\prime}-\mathrm{A}-\mathrm{B}\right)+\mathrm{A}^{\circ} \varepsilon_{\mathrm{t}-1} \varepsilon_{\mathrm{t}-1}+\mathrm{B}^{\circ} \mathrm{Q}_{\mathrm{t}-1}$

$\mathrm{R}_{\mathrm{t}}=\operatorname{diag}\left\{\mathrm{Q}_{\mathrm{i}}\right\}^{-1} \mathrm{Q}_{\mathrm{t}} \operatorname{diag}\left\{\mathrm{Q}_{\mathrm{i}}\right\}^{-1}$

Untuk logaritma penaksir atau Log Likehood adalah sebagai berikut:

$$
\mathrm{r}_{\mathrm{t}} \mid=_{\mathrm{t}-1} \sim \mathrm{N}\left(0, \mathrm{H}_{\mathrm{t}}\right)
$$

$\mathrm{L}=-\frac{1}{2} \sum_{\mathrm{t}-1}^{\mathrm{T}}\left(\mathrm{n} \log (2 \pi)+\log \left|\mathrm{H}_{\mathrm{t}}\right|+\mathrm{r}_{\mathrm{t}}^{\mathrm{s}} \mathrm{H}_{\mathrm{t}}^{-1} \mathrm{r}_{\mathrm{t}}\right.$

$=-\frac{1}{2} \sum_{\mathrm{t}-1}^{\mathrm{T}}\left(\mathrm{n} \log (2 \pi)+\log \left|\mathrm{D}_{\mathrm{t}} \mathrm{R}_{\mathrm{t}} \mathrm{D}_{\mathrm{t}}\right|+\mathrm{rt} \mathrm{Dt}-1 \mathrm{Rt}-1 \mathrm{Dt}-1 \mathrm{rt}\right.$

$=-\frac{1}{2} \sum_{t-1}^{\mathrm{T}}\left(\mathrm{n} \log (2 \pi)+\log \left|\mathrm{D}_{\mathrm{t}} \mathrm{R}_{\mathrm{t}} \mathrm{D}_{\mathrm{t}}\right|+\log |\mathrm{Rt}|+\varepsilon^{\prime} \mathrm{t} \mathrm{Rt}-1 \varepsilon \mathrm{t}\right)$

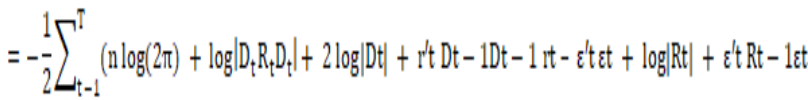

Newey \& McFadden (1994) menjelaskan bahwa perumusan model dilakukan ke dalam konsistensi dan normalitas asimtotik dari parameter yang memenuhi syarat, jika parameter $\mathrm{D}$ dicatat dengan $\phi$ dan parameter tambahan dalam $\mathrm{R}$ dicatat dengan $\theta$, Loglikelihood dapat dinyatakan sebagai jumlah volatilitas parsial dan korelasi sebagai berikut $\mathrm{L}(\theta, \phi)=\mathrm{LV}(\theta)+\operatorname{LC}(\theta, \phi)$.

Rumus dari volatilitas adalah sebagai berikut:

$(\theta)=-1 / 2 \sum\left(n \log (2 \pi)+\log \left|D_{t}\right|^{2}+r_{t}{ }^{\prime} D_{t^{-2}} r_{t}\right)$

Komponen dari korelasi adalah sebagai berikut:

$(\theta, \phi)=-1 / 2 \sum\left(\log \left|R_{t}\right|+\varepsilon_{t}{ }^{\prime} R_{t}{ }^{-1} \varepsilon_{t}-\varepsilon_{t}{ }^{\prime} \varepsilon_{t}\right)$

Partital volatilitas adalah jumlah dari GARCH likelihood tiap individu:

$\left.\left.L V(\varnothing)=-\frac{1}{2} \sum_{\mathrm{t}} \sum_{\mathrm{i}}^{\mathrm{n}}=0(\mathrm{n} \log (2 \mathrm{~m}))+\log (\mathrm{hi}, \mathrm{t})+r_{\mathrm{i}, \mathrm{t}} / h_{\mathrm{i}, \mathrm{t}}\right)\right)$

Jika digabungkan dapat dimaksimalkan dengan mengoptimalkan setiap istilah. Bagian kedua dari kemungkinan dilakukan untuk memperkirakan parameter korelasi. Mempertimbangkan residu kuadrat ini tidak terikat dengan parameter ini, sehingga hal-hal itu tidak dapat terlibat dalam kondisi urutan pertama dan harus diabaikan. Estimator yang dihasilkan kemudian disebut DCC LL INT, karena menggunakan model terintegrasi. Pendekatan dua langkah untuk mengoptimalkan kemungkinan digunakan untuk menghasilkan 
$\theta=\arg \max (L V(\theta)) \mid$

Nilai tersebut melangkah pada step ke dua: $\max \{\phi L C(\theta, \phi)\}$

Model DCC-GARCH juga telah digunakan oleh Stefan \& Robiyanto (2019) dalam mempelajari korelasi dinamis pasar saham Asean dengan nilai tukar dollar Amerika Serikat (USD) di era Donald Trump.

\section{HASIL}

\section{Statistika Deskriptif}

Tabel 1 menunjukkan statistika deskriptif dari return pasar saham yang digunakan dalam penelitian ini. Berdasarkan Tabel 1 dapat dilihat bahwa nilai mean dari KOSPI menunjukkan nilai yang lebih tinggi jika dibandingkan dengan indeks pasar modal yang lain, dan di lain sisi indeks IHSG menunjukkan nilai mean terendah. Jika dilihat minimumnya semua indeks saham yang diteliti ternyata memiliki nilai negatif, hal ini berarti selama masa pandemi Covid-19 ini mengakibatkan baik Indonesia, Asia maupun dunia mengalami krisis ekonomi dan menjadikan pasar saham melemah.

Nilai standar deviasi menunjukkan risiko dari suatu portofolio investasi. Risiko yang dimaksud mencakup risiko pasar maupun risiko yang berasal dari portofolio itu sendiri. Semakin besar standar deviasi maka semakin besar pula risiko dari saham tersebut (Giharta \& Sedana, 2017). Berdasarkan Tabel 1 indeks saham yang memiliki risiko paling tinggi adalah ASX dengan nilai standar deviasi sebesar 0,037223. Disisi lain indeks saham yang memiliki risiko terendah dari semua indeks yang diteliti adalah KLSE dengan nilai standar deviasi sebesar 0,013496.

Tabel 1. Statistika Deskriptif

\begin{tabular}{lcrrrr}
\hline & $\mathrm{N}$ & \multicolumn{1}{c}{ Maximum } & \multicolumn{1}{c}{ Minimum } & \multicolumn{1}{c}{ Mean } & \multicolumn{1}{c}{ Std Deviation } \\
\hline ASX & 167 & 0,142 & $-0,124$ & 0,001 & 0,037 \\
DOWJONES & 167 & 0,095 & $-0,123$ & 0,001 & 0,027 \\
FTSE & 167 & 0,091 & $-0,109$ & $-0,001$ & 0,021 \\
HANGSENG & 167 & 0,051 & $-0,090$ & $-0,000$ & 0,017 \\
IHSG & 167 & 0,102 & $-0,079$ & $-0,000$ & 0,021 \\
KLSE & 167 & 0,036 & $-0,053$ & 0,000 & 0,014 \\
KOSPI & 167 & 0,086 & $-0,128$ & 0,002 & 0,021 \\
NIKKEI & 167 & 0,071 & $-0,061$ & 0,001 & 0,017 \\
PSEI & 167 & 0,131 & $-0,133$ & $-0,000$ & 0,026 \\
SET & 167 & 0,099 & $-0,108$ & $-0,000$ & 0,022 \\
STI & 167 & 0.058 & -0.060 & $-0,001$ & 0,017 \\
TAIPEI WG & 167 & 0,049 & $-0,080$ & 0,001 & 0,015 \\
\hline
\end{tabular}

\section{Hasil Uji Stasioneritas}

Hasil dari uji stasioneritas data dapat dilihat pada Tabel 2. Uji stasioneritas dihitung menggunakan augmented Dickey-Fuller (ADF) (Dickey \& Fuller, 1981). Berdasarkan Tabel 2 dilihat bahwa data yang digunakan dalam penelitian ini memiliki nilai t-Statisitic lebih besar dari ADF dengan signifikansi di tingkat $1 \%$ maka artinya semua data dalam penelitian ini stasioner dan diindikasikan tidak memiliki unit root.

\section{Hasil Analisis Korelasi}

Berdasarkan hasil analisis korelasi yang terdapat pada Tabel 3, dapat dilihat bahwa semua indeks pasar saham yang diteliti memiliki korelasi yang signifikan dengan nilai signifikansi sebesar $5 \%$. Hal ini menunjukkan bahwa semua pasar saham yang dipelajari saling berkorelasi satu sama lain.

Tabel 2. Hasil Uji Stasioneritas

\begin{tabular}{llr}
\hline No & Indeks & t-Statistic \\
\hline 1 & ASX & $-15,270^{*}$ \\
2 & DOWJONES & $-16,987^{*}$ \\
3 & FTSE & $-13,483^{*}$ \\
4 & HANGSENG & $-12,965^{*}$ \\
5 & HSG & $-11,733^{*}$ \\
6 & KLSE & $-6,923^{*}$ \\
7 & KOSPI & $-10,968^{*}$ \\
8 & NIKKEI & $-10,553^{*}$ \\
9 & PSEI & $-7,577^{*}$ \\
10 & SET & $-7,251^{*}$ \\
11 & STI & $-11,094^{*}$ \\
12 & TAIPEI WG & $-10,099^{*}$ \\
\hline
\end{tabular}

Keterangan: *Signifikan pada level 0,01 
Tabel 3. Hasil Analisis Korelasi

\begin{tabular}{|c|c|c|c|c|c|c|c|c|c|c|c|c|}
\hline & ASX & $\begin{array}{l}\text { DOWJ } \\
\text { ONES }\end{array}$ & FTSE & $\begin{array}{c}\text { HANGS } \\
\text { ENG }\end{array}$ & IHSG & KLSE & KOSPI & NIKKEI & PSEI & SET & STI & $\begin{array}{c}\text { TAIW } \\
\text { AN }\end{array}$ \\
\hline ASX & 1,000 & 0,740 & 0,662 & 0,522 & 0,410 & 0,287 & 0,570 & 0,387 & 0,498 & 0,471 & 0,504 & 0,599 \\
\hline DOWJONES & 0,740 & 1,000 & 0,754 & 0,470 & 0,476 & 0,239 & 0,465 & 0,429 & 0,420 & 0,551 & 0,539 & 0,433 \\
\hline FTSE & 0,662 & 0,754 & 1,000 & 0,572 & 0,499 & 0,364 & 0,563 & 0,557 & 0,521 & 0,673 & 0,617 & 0,528 \\
\hline HANGSENG & 0,522 & 0,470 & 0,572 & 1,000 & 0,588 & 0,594 & 0,737 & 0,604 & 0,570 & 0,607 & 0,776 & 0,724 \\
\hline IHSG & 0,410 & 0,476 & 0,499 & 0,588 & 1,000 & 0,553 & 0,644 & 0,547 & 0,666 & 0,610 & 0,704 & 0,633 \\
\hline KLSE & 0,287 & 0,239 & 0,364 & 0,594 & 0,553 & 1,000 & 0,618 & 0,583 & 0,583 & 0,550 & 0,641 & 0,630 \\
\hline KOSPI & 0,570 & 0,465 & 0,563 & 0,737 & 0,644 & 0,618 & 1,000 & 0,737 & 0,609 & 0,544 & 0,746 & 0,830 \\
\hline NIKKEI & 0,387 & 0,429 & 0,557 & 0,604 & 0,547 & 0,583 & 0,737 & 1,000 & 0,418 & 0,552 & 0,651 & 0,696 \\
\hline PSEI & 0,498 & 0,420 & 0,521 & 0,570 & 0,666 & 0,583 & 0,609 & 0,418 & 1,000 & 0,599 & 0,657 & 0,617 \\
\hline SET & 0,471 & 0,551 & 0,673 & 0,607 & 0,610 & 0,550 & 0,544 & 0,552 & 0,599 & 1,000 & 0,679 & 0,527 \\
\hline STI & 0,504 & 0,539 & 0,617 & 0,776 & 0,704 & 0,641 & 0,746 & 0,651 & 0,657 & 0,679 & 1,000 & 0,693 \\
\hline TAIWAN & 0,599 & 0,433 & 0,528 & 0,724 & 0,633 & 0,630 & 0,830 & 0,696 & 0,617 & 0,527 & 0,693 & 1,000 \\
\hline
\end{tabular}

\section{Hasil Granger Causality Test}

Uji Kausalitas Granger digunakan untuk mengetahui hubungan sebab akibat dari masing-masing variabel independen terhadap variabel dependen (Purnomo, 2001). Pada penelitian ini, uji kausalitas lebih ditunjukkan kepada faktor penyebab terjadinya kointegrasi pasar modal Asia dan dunia terhadap pasar modal Indonesia, dimana pasar saham Asia dan dunia itu sendiri terdiri dari ASX, DOWJONES, FTSE, HANGSENG, KLSE, KOSPI, NIKKEI, PSEI, SET, STI, dan TAIWAN sebagai leading indicator (indikator yang mempengaruhi perubahan harga) bagi IHSG. Taraf uji yang digunakan dalam Uji Kausalitas Granger ini, yaitu tingkat kepercayaan 0,05 (5 persen) dan panjang lag sampai pada lag 2 sesuai pengujian panjang lag optimum yang telah dilakukan. Hasil analisis Kausalitas Granger ditunjukkan dalam Tabel 4 dapat dijelaskan bahwa yang memiliki hubungan kausalitas adalah variabel dengan nilai probabilitas lebih kecil dari a 0,05.

Berdasarkan hasil Uji Kausalitas Granger seperti yang ditunjukkan pada Tabel 4 terlihat bahwa IHSG saling berpengaruh satu sama lain dengan indeks ASX, begitu pula dengan indeks DOWJONES, KLSE, NIKKEI, STI, dan TAIWAN. Di samping itu ditemukan bahwa IHSG ternyata tidak mempengaruhi indeks FTSE, HANGSENG, KOSPI, PSEI, dan SET.

Tabel 4. Hasil Granger Causality Test

\begin{tabular}{|c|c|c|}
\hline Null Hyphothesis & F-Statistic & Prob \\
\hline ASX does not Granger Cause IHSG & $4,13539 *$ & 0,0177 \\
\hline IHSG does not Granger Cause ASX & 1,40337 & 0,2488 \\
\hline DOWJONES does not Granger Cause IHSG & $3,82807^{*}$ & 0,0238 \\
\hline IHSG does not Granger Cause DOWJONES & 2,08629 & 0,1275 \\
\hline FTSE does not Granger Cause IHSG & $5,24902^{* *}$ & 0,0062 \\
\hline IHSG does not Granger Cause FTSE & 0,39886 & 0,6717 \\
\hline HANGSENG does not Granger Cause IHSG & $4,76592^{* *}$ & 0,0098 \\
\hline IHSG does not Granger Cause HANGSENG & 0,05971 & 0,9421 \\
\hline KLSE does not Granger Cause IHSG & $14,7953^{* *}$ & 1,E-06 \\
\hline IHSG does not Granger Cause KLSE & 1,05630 & 0,3502 \\
\hline KOSPI does not Granger Cause IHSG & $16,7400 * *$ & 3,E-07 \\
\hline IHSG does not Granger Cause KOSPI & 0,31983 & 0,7267 \\
\hline NIKKEI does not Granger Cause IHSG & $7,76959 * *$ & 0,0006 \\
\hline IHSG does not Granger Cause NIKKEI & 1,27651 & 0,2818 \\
\hline PSEI does not Granger Cause IHSG & $5,00248^{* *}$ & 0,0078 \\
\hline IHSG does not Granger Cause PSEI & 0,33223 & 0,7178 \\
\hline SET does not Granger Cause IHSG & $6,28436^{* *}$ & 0,0024 \\
\hline IHSG does not Granger Cause SET & 0,07294 & 0,9297 \\
\hline STI does not Granger Cause IHSG & $7,61832^{* *}$ & 0,0007 \\
\hline IHSG does not Granger Cause STI & 0,67994 & 0,5081 \\
\hline TAIWAN does not Granger Cause IHSG & $13,4921^{* *}$ & 4,E-06 \\
\hline IHSG does not Granger Cause TAIWAN & 1,02165 & 0,3623 \\
\hline
\end{tabular}

Keterangan: **Signifikan pada level 0,01 dan *Signifikan pada level 0,05 

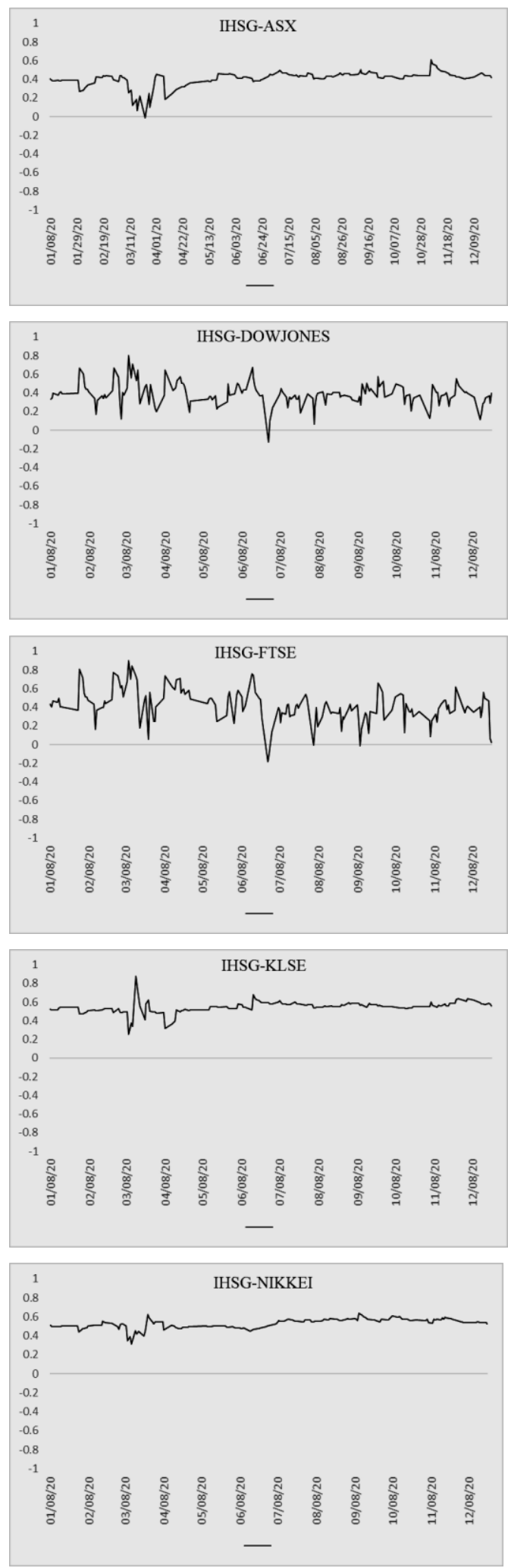
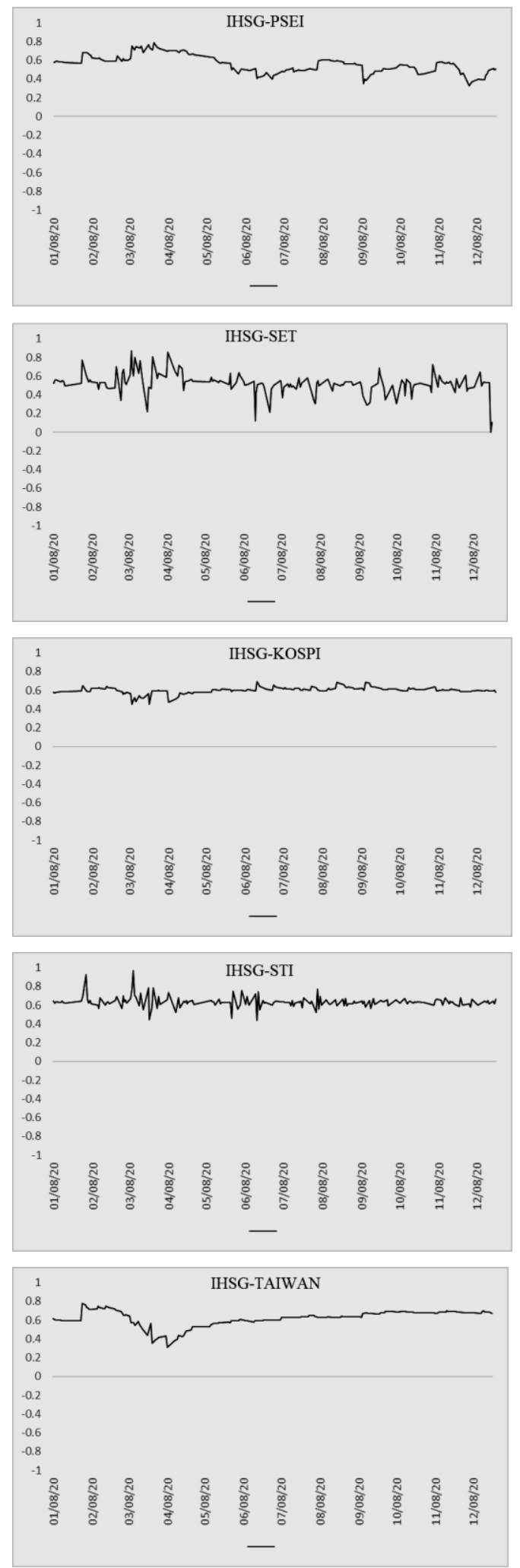


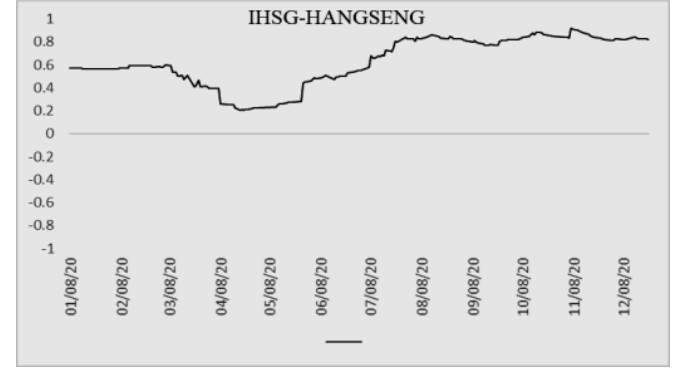

Gambar 1 DCC IHSG - Beberapa Indeks Saham Asia dan Dunia (Januari - Desember 2020)

Sumber: www.Investing.com

Gambar 1 menunjukkan grafik hasil analisis DCC-GARCH meliputi 12 indeks saham yang diteliti. Nilai DCC turun ke titik terendah saat awal pandemi mulai bergejolak memasuki Indonesia pada sekitar bulan Maret dan April. Indeks tersebut antara lain ASX dengan titik terendah di angka -0,0098, KOSPI di angka 0,4486, HANGSENG di angka 0,2036 dan TAIWAN dia angka 0,3102 . Titik terendah indeks lainnya seperti STI di angka 0,4371, DOWJONES di angka -0,1292 dan FTSE di angka $-0,1868$ terjadi di pertengahan tahun yakni pada bulan Juli dimana kasus pandemi mulai berangsur menyebar merata ke berbagai daerah di Indonesia. Sedangkan indeks lainnya yakni PSEI dan SET memiliki titik terendah di akhir tahun bulan Desember di angka 0,3284 dan 0,0020 dimana kasus positif Covid-19 di Indonesia memuncak drastis.

Sementara itu, nilai DCC indeks saham yang justru berada di titik tertinggi saat periode awal pandemi yakni antara bulan februari dan Maret yaitu TAIWAN di angka 0,7773, STI di angka 0,9662, DOWJONES di angka 0,8004, FTSE di angka 0,8958, PSEI di angka 0,7849 dan SET di angka 0,8675 . Indeks lain yang berada di titik tertinggi pada pertengahan tahun dimana mulai diberlakukan pembatasan sosial berskala besar antara bulan Juni sampai Agustus yakni HANGSENG, KOSPI yang berada di titik 0,9178, dan 0,6956. Sedangkan ASX berada di titik tertinggi pada bulan November di titik 0,6114 dimana di Indonesia sudah memasuki masa normal baru yakni masa pemulihan perekonomian dan dilonggarkannya lagi pembatasan sosial.

Indeks lain yang diteliti yakni KLSE dan NIKKEI memiliki nilai DCC di titik terendah dan tertinggi sekaligus di bulan Maret yakni di kisaran 0,2568 sampai 0,8762 dan 0,3111 sampai 0,6362. Kedua indeks saham ini pulih dengan cepat dari pengaruh penyebaran pandemi Covid-19 yang mengakibatkan gejolak di pasar saham.

\section{PEMBAHASAN}

Berdasarkan analisis yang dilakukan oleh DCC-GARCH seperti yang ditunjukkan pada Gambar 1, terlihat bahwa dengan menggunakan DCC-GARCH, korelasi antara IHSG dengan beberapa indeks pasar saham yang diteliti terlihat berubah secara dinamis dari waktu ke waktu. Hasil penelitian menunjukkan bahwa terdapat efek penularan yang terjadi pada periode saat terjadinya krisis pandemi Covid-19. Efek tersebut berupa pengaruh yang timbul atas krisis yang mengakibatkan terjadinya perubahan harga saham pada suatu negara. Perubahan tersebut memicu terjadinya pergerakan harga saham di negara lain atau yang disebut dengan contagion effect (Ikrima \& Muharam, 2014). Hal ini serupa dengan penelitian Robiyanto (2018) yang menyimpulkan bahwa DCC-GARCH mampu menunjukkan keterkaitan antar pasar saham dari waktu ke waktu. Selain itu penelitian ini juga sejalan dengan penelitian Catherine \& Robiyanto (2020), Tresna Wira Sentana \& Baskara (2020), serta Suganda \& Soetrisno (2016) yang menemukan bahwa terdapat integrasi antara pasar modal yang berada di kawasan Asia dan dunia. Berdasarkan hasil temuan, maka hipotesis yang menyatakan adanya integrasi antara pasar saham Indonesia dengan pasar saham di kawasan ASEAN dan pasar saham dunia selama pandemi Covid-19.

\section{SIMPULAN DAN SARAN}

Dengan menggunakan DCC-GARCH, penelitian menemukan bahwa hubungan dinamis antara pasar saham Indonesia dengan pasar saham di Asia dan dunia selalu berubah dari waktu ke waktu. Nilai DCC-GARCH antara IHSG dan indeks pasar saham yang diteliti cenderung bervariasi. Sejalan dengan penelitian sebelumnya, penelitian ini juga menemukan bahwa pasar saham Indonesia dengan pasar saham di Asia dan dunia terintegrasi. Hal ini menjelaskan bahwa pergerakan harga saham di Indonesia masih dipengaruhi oleh pergerakan harga saham di negara lain dengan tingkat pegaruh yang berbeda-beda. Hasil penelitian menunjukkan bahwa terdapat efek penularan (contagion effect) yang terjadi pada periode saat terjadinya krisis pandemi Covid-19.

Berdasarkan temuan tersebut, pemerintah Indonesia perlu melaksanakan kebijakan-kebijakan khusus untuk mengatasi krisis ekonomi dengan memperhatikan nilai indeks harga saham 
yang beredar terutama saat dampak dari pandemi Covid-19 berlangsung. Temuan dalam penelitian ini juga membuktikan bahwa pasar saham baik Indonesia, Asia dan dunia terintegrasi secara dinamis akibat krisis yang terjadi. Hal ini berarti bagi Investor perlu merencanakan strategi investasi khusus dan perlu memperhatikan nilai indeks harga saham yang beredar dan berbagai isu yang tersebar di Negara sebelum mengambil tindakan untuk berinvestasi di Negara tersebut karena memiliki pengaruh signifikan dan juga memiliki hubungan yang kuat setelah isu tersebut sehingga para investor bisa melihat hubungan pasar modal yang akan diinvestasikannya.

Selain itu penelitian ini menunjukkan pentingnya penggunaan pendekatan dinamis dalam analisis integrasi pasar saham. Karena studi ini menjadi pionir dalam pendekatan ini dan hanya ada sedikit pasar saham yang diteliti, studi selanjutnya dapat memperluas cakupan pasar saham yang dianalisis. Penulis selanjutnya diharapkan agar menggunakan alat analisis lainnya dan juga Negara lainnya sehingga biasa membandingkan dan melihat apakah masih secara signifikan pasar saham Indonesia, Asia dan dunia saling terintegrasi selama pasca pandemi Covid19 berlangsung.

\section{DAFTAR PUSTAKA}

Catherine, H., \& Robiyanto, R. (2020). Integrasi Pasar Modal di Kawasan Asia dan Amerika Serikat Pasca Pelantikan Donald Trump. Jurnal Ilmiah MEA, 4(3), 1-16. https://doi.org/https://doi.org/10.31955/ mea.vol4.iss3.pp1-17

Darrat, A. F., Elkhal, K., \& Hakim, S. R. (2000). On the Integration of Emerging Stock Markets in the Middle East. On the Integration of Emerging Stock Markets in the Middle East, 25(2),

119-129.

https://www.researchgate.net/publication/ 227450269_On_the_Integration_of_Emerging _Stock_Markets_in_the_Middle_East

Dewi, C. K., \& Masithoh, R. (2020). JKSE and Trading Activities Before After Covid-19 outbreak. Journal of Accounting and Business Management, 4(1), 1-6. https://doi.org/10.31293/rjabm.v4i1.4671

Dickey, D. A., \& Fuller, W. A. (1981). Likelihood Ratio Statistics for Autoregressive Time Series with a Unit Root. Econometrica, 49(4), 1057-1072. https://doi.org/10.2307/1912517

Engle, R. (2002). Dynamic conditional correlation:
A simple class of multivariate generalized autoregressive conditional heteroskedasticity models. Journal of Business and Economic Statistics, 20(3), 339-350. https://doi.org/10.1198/07350010228861848 7

Ersabathari, R. V., \& Muharam, H. (2017). Integrasi Pasar Modal Asean 6 Periode Tahun 2007-2016. Diponegoro Journal of Management, 6(3), 1-15. http://ejournals1.undip.ac.id/index.php/dbr

Giharta, A. S., \& Sedana, I. B. P. (2017). Pembentukan Portofolio Optimal Pada Saham-saham Perusahaan Sub-Sektor Konstruksi Bangunan di Bursa Efek Indonesia (Pendekatan Markowitz). E-Jurnal Manajemen Unud, 6(9), 4716-4743.

Hwang, J. (2012). Dynamic Correlation Analysis of Asian Stock Markets. International Atlantic Economic Society, 18(1), 227-237. https://doi.org/10.1007/s11294-012-9343-6

Kontan. (2020). IHSG Menguat 0,23\%, Asing Mencatat Net Buy dan Net Sell Terbesar di Saham Bank. https://investasi.kontan.co.id/news/ihsgmenguat-023-asing-mencatat-net-buy-dannet-sell-terbesar-di-saham-bank

Mohti, W., Dionísio, A., Vieira, I., \& Ferreira, P. (2019). Research in International Business and Finance Regional and global integration of Asian stock markets. Research in International Business and Finance, 50(11), 357368.

https://doi.org/10.1016/j.ribaf.2019.06.003

Newey, W. K., \& McFadden, D. (1994). Large Sample Estimation and Hypothesis Testing. Handbook of Econometrics, 4, 2111-2245. https://doi.org/10.1016/S15734412(05)80005-4

Purnomo, D. (2001). Penggunaan Metode Granger Untuk Uji Kausalitas. Jurnal Ekonomi Pembangunan, 2(1), 91-100.

Rasydin, R. (2016). Integrasi Pasar Modal ASEAN Pasca Pemberlakuan MEA. Jurnal Visioner \& Strategis, 21(5-6), 1-49. https://doi.org/https://doi.org/10.1080/00 102208008946937

Robiyanto, R. (2018). Indonesian Stock Market's Dynamic Integration with Asian Stock Markets and World Stock Markets. Jurnal Pengurusan, 52, 181-192. https://doi.org/10.17576/pengurusan-201852-15

Sakthivel, P., Bodkhe, N., \& Kamaiah, B. (2012). 
Correlation and Volatility Transmission across International Stock Markets: A Bivariate GARCH Analysis. International Journal of Economics and Finance, 4(3), 253264. https:// doi.org/10.5539/ijef.v4n3p253

Shiyammurti, N. R., Saputri, D. A., \& Syafira, E. (2020). Dampak Pandemi Covid-19 Di PT. Bursa Efek Indonesia (BEI). Journal of Accounting Taxing and Auditing, 1(1), 1-5. http://www.jurnal.umitra.ac.id/index.php/ JATA/article/view/268

Stefan, Y. A., \& Robiyanto, R. (2019). Korelasi Dinamis Pasar Saham ASEAN dengan Nilai Tukar Dollar Amerika Serikat (USD). Jurnal Ilmu Sosial Dan Humaniora, 8(2), 131-134. https://doi.org/10.23887/jishundiksha.v8i2.21380

Suganda, T. R., \& Soetrisno, Y. (2016). Uji Integrasi Dan Contagion Effect Pasar Modal Pada Lima Negara Asean (Riset Empiris Pasca Terjadinya Krisis Subprime Mortgage Dan Krisis Yunani). Jurnal Keuangan Dan Perbankan, 20(2), 252-262. https://doi.org/10.26905/jkdp.v20i2.358

Tandelilin, E. (2010). Dasar-dasar Manajemen Investasi http://repository.ut.ac.id/3823/1/EKMA53 12-M1.pdf

Tresna Wira Sentana, I. W., \& Baskara, I. G. K. (2020). Integrasi Indeks Saham Pada Bursa Negara Kawasan Asia Pasifik. J-MKLI (Jurnal Manajemen Dan Kearifan Lokal Indonesia), 4(1), 30. https://doi.org/10.26805/jmkli.v4i1.81

Utama, I. W. A. B., \& Artini, L. G. S. (2013). Pengaruh Indeks Bursa Dunia pada Indeks Harga Saham Gabungan Bursa Efek Indonesia. Jurnal Manajemen, Strategi Bisnis Dan Kewirausahaan, 9(1), 65-73. https://ojs.unud.ac.id/index.php/jmbk/arti cle/view/14401

WHO. (2020). Coronavirus: Window of opportunity to act, World Health Organization says. $B B C$. https://www.bbc.com/news/world-asiachina-51368873 